\title{
First Fossil Record of Totoaba Villamar 1980 (Teleostei: Sciaenidae) Based upon Early Miocene Otoliths from California with Comments on the Ontogeny of the Saccular Otolith
}

\author{
Richard W. Huddleston ${ }^{1,2}$ and Gary T. Takeuchi ${ }^{2}$ \\ ${ }^{1}$ Scientific Research Systems, 11044 McGirk Avenue, \\ El Monte, California 91731 \\ ${ }^{2}$ Department of Vertebrate Paleontology, Natural History Museum of Los \\ Angeles County, 900 Exposition Boulevard, Los Angeles, California 90007
}

Abstract.-A new species of the genus Totoaba (family Sciaenidae) based upon otoliths from the late early Miocene marine upper Olcese Sand, Kern County, southern San Joaquin Valley, California is described. This is the first fossil occurrence for the genus, and it is hypothesized that Totoaba evolved entirely in the eastern Pacific realm. Within the upper Olcese Sand, this species represents but one component of a complex sciaenid fauna, which could provide insight into the evolution and distribution of the family Sciaenidae. An ontogenetic series of this species is defined, and ontogenetic changes in its otoliths are discussed.

Totoaba Villamar 1980 is represented by a single extant species, T. macdonaldi (Gilbert 1890), and is the largest of about 270 extant sciaenid species (croakers and drums) with a length of over $200 \mathrm{~cm}$ (Chao 1995) and a maximum reported weight of over $100 \mathrm{~kg}$ (Barrera-Guevara 1990). Many aspects of the biology and ecology of this species are poorly known. This demersal species is endemic to the Gulf of California, Mexico; it once supported an important commercial and sport fishery, which was based on its annual spring breeding migration to the shallow, formerly brackish, waters of the Colorado River delta at the north end of the Gulf. Totoaba macdonaldi once ranged from the mouth of the Colorado River to Bahia Concepcion on the west coast of the Gulf of California and to the mouth of the El Fuerte River in the east (Berdegue 1955), but is now restricted to the northern Gulf. In 1976, as a result of overfishing and habitat alteration, this species was placed on the endangered list of the Convention on International Trade in Endangered Species (CITES) (Berdegue 1955; Flanagan and Hendrickson 1976; Cisneros-Mata et al. 1995). Recent studies support evidence of a small, but stable, population of Totoaba in the northern Gulf of California (CisnerosMata et al. 1995; Roman-Rodriguez and Hammann 1997).

Villamar (1980) established the genus Totoaba to separate Cynoscion macdonaldi Gilbert 1890 from Cynoscion Gill 1861. The new genus was based on swimbladder morphology, saccular otoliths, pores on the dentary, and submaxillar folds. He noted features of the swimbladder in Totoaba more closely resembled the Indo-West Pacific genus Bahaba Herre 1935 than Cynoscion. Schwarzhans (1993) in his treatise of the recent and fossil otolith of the Sciaenidae recognized 21 "groupings" according to their otolith morphology. He noted that the saccular otoliths of Totoaba have a combination of plesiomorphic characters similar to other sciaenid groups such as the Sciaena, Pogonias, or Bahaba groups and con- 
sidered that within the Cynoscion Group, the otoliths were most similar to Atractoscion Gill 1862. Otoliths of Atractoscion differ mainly in the moderate to strongly developed postcentral umbo on the outer face, which is true for otoliths of Bahaba. Based on these similarities, Schwarzhans (1993) provisionally retained Totoaba within the Cynoscion Group but acknowledged that the swimmbladder pattern "points to radically different systematic position." A phylogenetic analysis for the Sciaenidae by Sasaki (1989) using morphological, osteological, and myological evidence placed Bahaba and Totoaba in the subfamily incertae sedis.

In the 1960's and early 1970's, the late John E. Fitch and field parties extensively bulk sampled matrix from numerous localities for fossil teleostean otoliths from the richly fossiliferous, shallow-marine Tertiary sediments of the southeastern San Joaquin Basin along the western flank of the Sierra Nevada east of Bakersfield, California. These sediments have yielded, in addition to otoliths, abundant marine invertebrates, locally rich concentrations of marine vertebrates, and very rare land mammal remains (e.g. Mitchell 1966; Addicott 1970a; Savage and Barnes 1972; Mitchell and Tedford 1973; Barnes 1976; Clarke and Fitch 1979; Barnes and Mitchell 1984). One area, Barker's Ranch, intensively sampled by Fitch in the fossiliferous upper Olcese Sand contains a diverse nearshore ichthyofauna dominated by numerous sciaenid otoliths. The sciaenids represent over $50 \%$ of the total number of otoliths and contain at least 12 sciaenid taxa that are recognized by the authors, including several forms now restricted to the Altantic and Indo-Pacific. This represents the largest sciaenid fauna from the west coast of North America.

Clarke and Fitch (1979:492) in a study of Cenozoic teuthoid (cephalopod) statoliths from North America, reported that a 1,800 kg sample from numerous sites in the "Barker's Ranch beds" produced more than 100,000 fish otoliths and several thousand teeth of sharks, skates, and rays, Cetorhinus sp. (basking shark) gill rakers, and hundreds of squid statoliths. The otolith assemblage consisted of more than 65 kinds of fish belonging to 30 or more families. Some of the forms mentioned include sciaenids (drums and croakers), pleuronectids and bothids (right- and left-eyed flatfishes), serranids (basses), atherinids (silversides), mugilids (mullets), gobiids (gobies), clupeids (herrings), and other nearshore forms. They also noted that deepwater forms (melamphaids (bigscale fishes), morids (morid cods) myctophids (lanternfishes), macrourids (rattails), etc.) are relatively rare. Unfortunately, Fitch never formally described the otoliths from the Barker's Ranch area before his untimely death on 30 September 1982. His entire collection of Recent and fossil otoliths, including notes, correspondence, and library, were donated to the Natural History Museum of Los Angeles County, Los Angeles, California (LACM) and are housed in the Department of Ichthyology. Examination of the Barker's Ranch collection by the authors as part of this study revealed a pre-catalogue inventory of approximately 21,271 otoliths, not the 100,000 reported in Clarke and Fitch (1979). Stringer (1998) noted a similar inconsistency in the number of otoliths reported by Clarke and Fitch (1979) from the Pliocene Bowden shell bed of Jamaica. These discrepancies are unexplained but are possibly overestimations by Fitch, and it is unlikely that there are missing otoliths.

Fish otoliths are the specialized hard parts of the actinopterygian and sarcopterygian acoustico-lateralis system, situated in the membranous labyrinths in the otic capsules of the neurocranium. Bony fishes (teleostean) have three otoliths 
(the saccular, utricular, and lagenar) in each of the two labyrinths. Saccular otoliths tend to be the largest of the otoliths and are the most widely used for species identification and evaluation of taxonomic relationships due to their size and morphological characteristics (Gaemers 1984; Nolf and Steurbaut 1989; Lombarte et al. 1991). In addition, fossil otolith assemblages consistently provide a more detailed and accurate account of Tertiary ichthyofaunas than the exclusive use of isolated skeletal components or articulated remains (Breard and Stringer 1995; Nolf 1995; Nolf and Stringer 2003). Fossil otoliths are found in a wide spectrum of sedimentary environments and are common fossils in many marine sediments. In contrast, the preservation of fish skeletons nearly always represents unusual environmental circumstances (Nolf 1985, 1995).

In this paper we report the first fossil record of the sciaenid genus Totoaba and describe a new species based upon saccular otoliths. An ontogenetic series of this new species is defined, and ontogenetic changes in sciaenid otoliths are discussed.

\section{Locality and Geology}

Type and referred specimens described in this paper were collected from the Barker's Ranch Locality, LACM locality 6602, which is located in the hilly region to the northeast of Bakersfield, Kern County, California (Fig. 1). Collections were made from near the top of the upper Olcese Sand (Clarke and Fitch 1979:492; Takeuchi and Huddleston 2006:85). The Olcese Sand, part of the Temblor Group, interfingers with the underlying Freeman Silt (early Miocene) and the overlying Round Mountain Silt (middle Miocene) and has been informally subdivided into three unconformity-bounded depositional sequences (lower, middle, and upper) based upon lithologic facies characteristics (Addicott 1970a). In the type area for this unit, Addicott (1970a) estimated that the Olcese Sand is 300-360 m thick. In outcrop, the lower Olcese Sand is composed of very fine-grained, silty marine sandstone with interbedded sandy and clayey siltstone. Although the Olcese Sand is predominantly a marine unit, the middle part of this unit is nonmarine with lenses of marine deposits and is distinguish by fine- to coarse-grained, often pumiceous, sandstone with occasional gravel lenses, strong cross bedding, and a bluish-grey color. The upper Olcese Sand, the most fossiliferous part of the unit, is a very fine- to fine-grained, marine sandstone, which grades into a sandy siltstone southwards toward the Kern River and into a siltstone westward in outcrop (Olson et al. 1986; Olson 1988, 1990). At the Barker's Ranch locality, the upper Olsece Sand is well exposed and is overlain by mottled siltstone of the lower Round Mountain Silt. It is stratigraphically $43.5 \mathrm{~m}$ thick and is composed of finegrained marine sandstone to sandy siltstone, infrequently faintly cross-bedded with interbeds of transported shells (Olson et al. 1986). This is also the area of Addicott's (1956, 1970a) Bucklarkia barkeriana zone (Barker's Ranch Fauna) and contains at least 116 species of mollusks. This zone includes gastropod assemblages of outer shelf to slope species such as Trophon kernensis (Addicott 1970a). It is interpreted to represent shelf deposits below normal wave base with frequent storm-induced, wave-formed beds and concentrated shell lags based upon abundant mollusks and foraminifera (Addicott 1970a; Olson et al. 1986; Olson 1990).

There is some uncertainty surrounding the exact stratigraphic provenance of LACM locality 6602. Clarke and Fitch (1979:492) placed the locality in the "upper part of the Olcese Sand." However, Barnes and Mitchell (1984:17) referred 


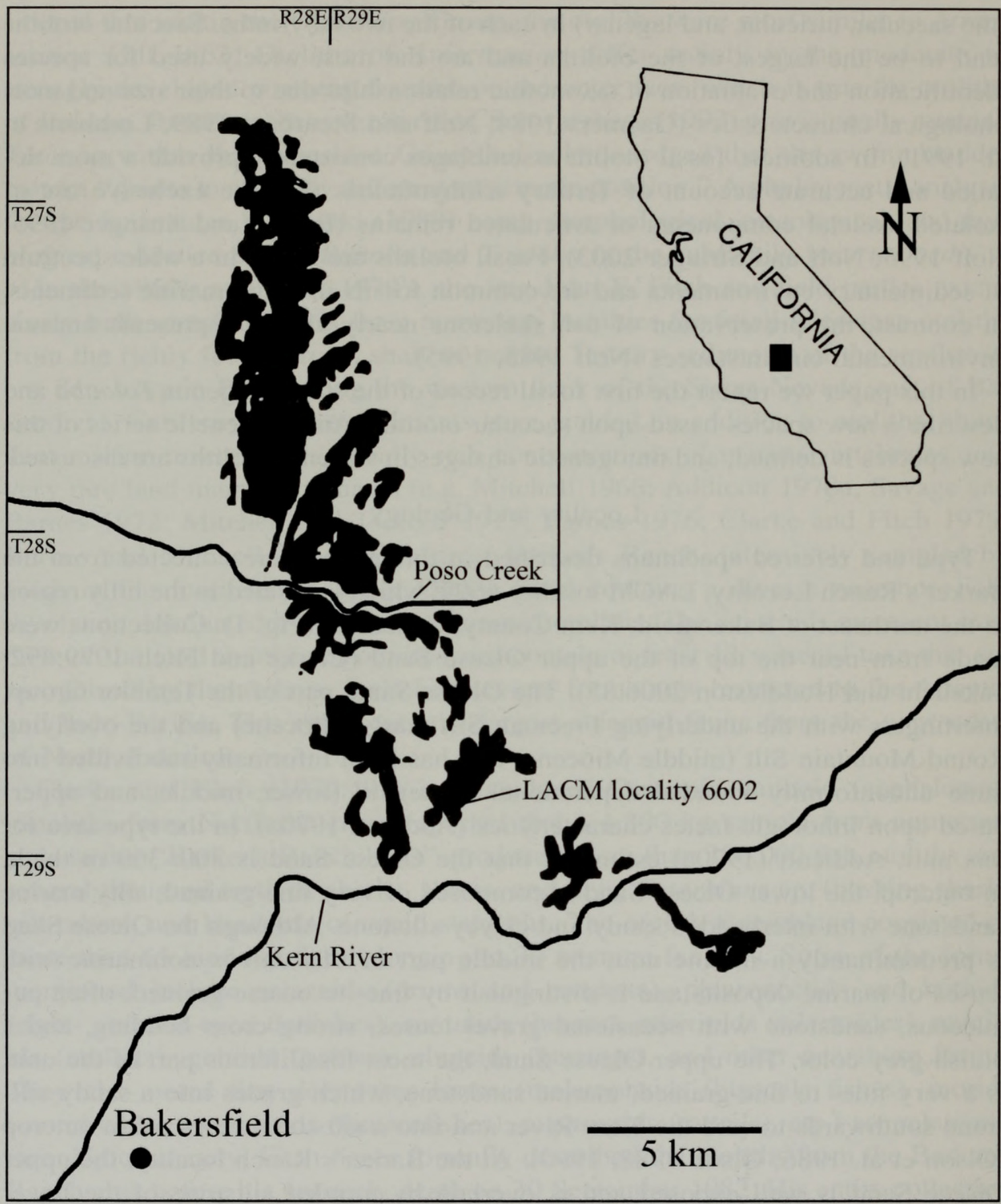

Fig. 1. Index map of the southeastern San Joaquin Basin north of Bakersfield, Kern County, California indicating collection site (LACM locality 6602) of Totoaba fitchi, sp. nov. (LACM 151552), holotype and referred specimens, late early Miocene, upper Olcese Sand. Local outcrops of the Olcese Sand indicated by shaded area. Modified after Olson (1990).

the locality to the "lower part of the Round Mountain Silt, below the Sharktooth Hill bone bed." Neither provided accurate stratigraphic nor locality data. Frequently, the delineation between the Olcese Sand and overlying Round Mountain Silt is indistinct due to a regressive event that separates the two units. A change in color and an increase in mica content in the Round Mountain Silt is the most noticeable character of the boundary (Olson 1990). In the Barker's Ranch area, the upper Olcese Sand is composed of fossiliferous very fine- to fine-grained, 
marine sandstone to sandy siltstone, with interbeds of transported shells, whereas the lowermost Round Mountain Silt is a mottled siltstone (Olson et al. 1986). The specimens described in this paper were found in a shell bed directly below a calcareously cemented sandstone that is approximately $14 \mathrm{~m}$ stratigraphically below a mottled siltstone. Thus, the type and referred specimens described in this paper are considered to be from sediments of the upper Olcese Sand.

A late early Miocene age for the upper Olcese Sand is based upon biostratigraphic correlation (Savage and Barnes 1972; Tedford et al. 1987:156; Tedford et al. 2004:fig. 6.2), benthic foraminiferal biostratigraphy (Olson 1990), and strontium isotope data (Olson 1988). Savage and Barnes (1972) correlated fragmentary land mammal remains (the Barker's Ranch Local Fauna) from the Barker's Ranch area with the late Hemingfordian North American Land Mammal Age (15.9-17.5 Ma). Strontium isotope results obtained from shell material near the top of the upper Olcese Sand at a nearby locality indicate an age of $16.7 \mathrm{Ma}$ (Olson 1988). This date is compatible with benthic foraminiferal biostratigraphy, which suggests an upper Relizian age and is, therefore, assignable to the late early Miocene.

\section{Material and Methods}

Comparative specimens used in this study include saccular otoliths of T. macdonaldi and are from the collections of the Department of Ichthyology, LACM and Marine Vertebrate Collection, Scripps Institution of Oceanography, University of California, San Diego, La Jolla, California (SIO). Additional comparative material was provided from a private collection.

The specimens described in this paper are housed in the collections of the Department of Vertebrate Paleontology, LACM. Uncatalogued and undescribed material from the Barker's Ranch locality is stored in the John E. Fitch Otolith Collection housed in the Department of Ichthyology, LACM. Bulk matrix samples were wet-screened and the remaining concentrated matrix was manually sorted under a dissecting microscope to remove identifiable otoliths, teeth, and bones. This method is fully described in Clarke and Fitch (1979:480-481). Specimens were photographed with a Nikon D70 digital camera.

Differences in proportional measurements were observed between smaller and larger otoliths of Totoaba and these differences were determined to be ontogenetic. In order to avoid confusion between ontogenetic and interspecific variation, for the purposes of our analysis, we define juvenile otoliths of Totoaba as those measuring less than $13 \mathrm{~mm}$ and adult otoliths of Totoaba measuring greater than $18 \mathrm{~mm}$ in length. Morphological terms (Fig. 2) used in the general description follow Nolf (1985) and Schwarzhans (1993). A pseudo-ostial sulcus is defined as a sulcus possessing an ostium that is completely contained within the otolith and does not reach the anterior margin except in specimens displaying some degree of erosion. Linear measurements were made on an EPOI Shopscope optical micrometer. Measurements and proportional ratios of the otolith for the Sciaenidae follow Schwarzhans (1993), and are described below. Otolith measurements are shown on Fig. 3. Measurements used for proportional ratios on the inner face include the following: otolith length (L) is the greatest anterior to posterior length; otolith height $(H)$ is the greatest dorsal to ventral height; ostium length (OL) is taken from the anterior edge of the ostium to the posterior most extension of the ostium, including the postostial lobe if present; ostium height $(\mathrm{OH})$ is the greatest 


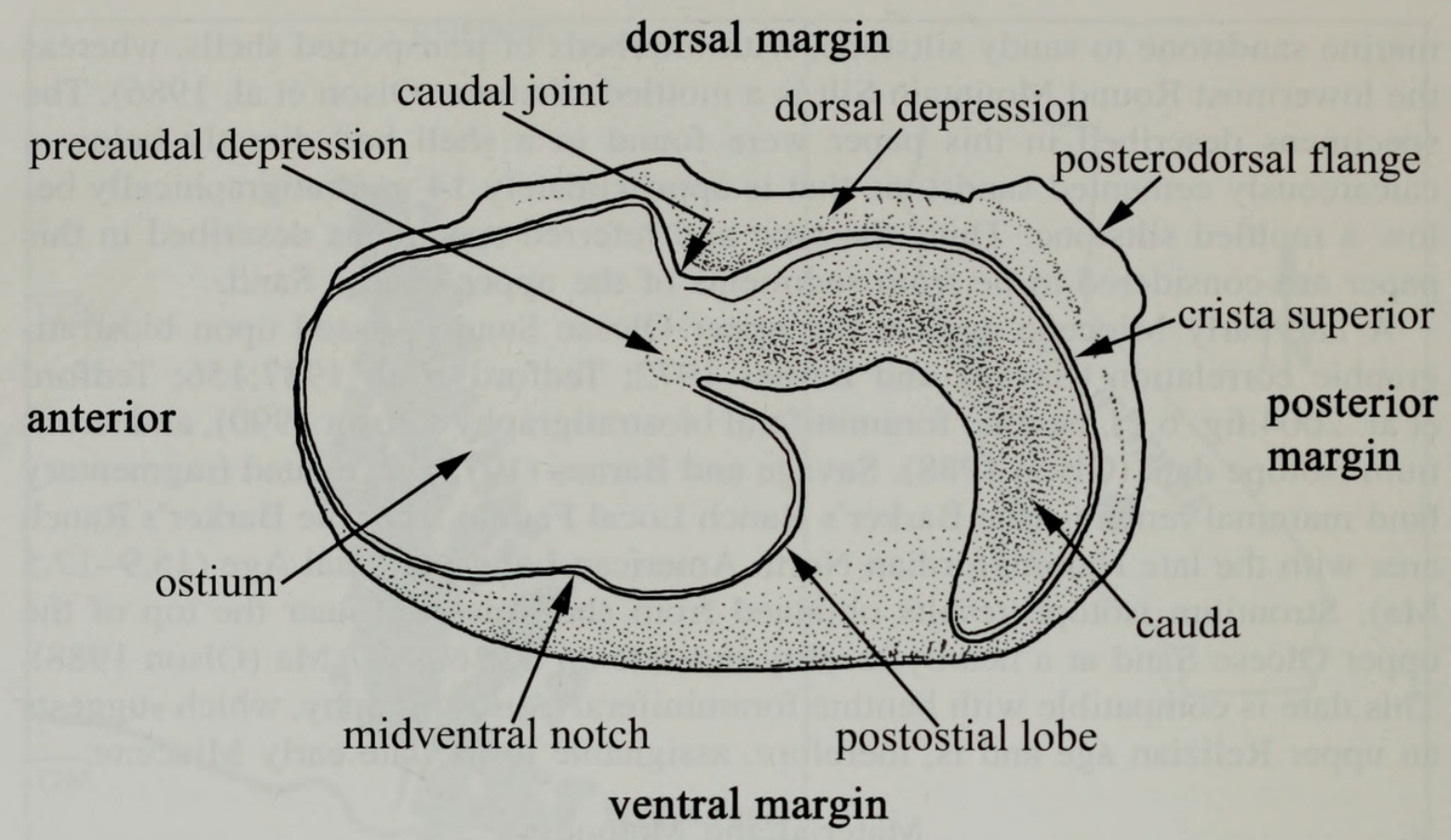

Fig. 2. Diagram of the inner face of a right saccular otolith of Totoaba illustrating its various diagnostic features. Modified after Schwarzhans (1993).

dorsal to ventral height of the ostium with the otolith in natural position; cauda length (CL) is measured from the dorsal edge of the cauda at the dorsal caudal joint and extending to the posterior most extension of the dorsal caudal margin; length of horizontal portion of the cauda $(\mathrm{X})$ is measured from the caudal joint of the ventral caudal margin and extending to the posterior most extension of the ventral caudal margin; length of down turned portion of cauda (Y) is from the highest point of the ventral caudal margin to the posterior-most point of the cauda termination. Measurement used for proportional ratio from lateral view: otolith thickness (T), is the greatest inner face to outer face thickness taken in dorsal view.

\section{Systematic Paleontology \\ Class Actinopterygii (sensu Nelson, 2006) \\ Division Teleostei (sensu Nelson, 2006) \\ Order Perciformes (sensu Johnson and Patterson, 1993) \\ Family Sciaenidae Cuvier, 1829 \\ Genus Totoaba Villamar, 1980}

Type-species.-Cynoscion macdonaldi Gilbert, 1890.

Generic diagnosis (emended from Schwarzhans 1993).- The saccular otolith is thick, massive, and slightly to moderately elongate with a rectangular to subrectangular outline, and all margins are nicely rounded. The dorsal margin is straight or slightly irregular. The anterior margin is blunted or gently curved with the ventral margin straight. The posterior margin is blunted, nearly vertical, and the posterodorsal margin has a short flange-like projection. The inner face of the otolith is moderately to strongly convex with a pseudo-ostial sulcus. The large spade-shaped ostium is flat and shallow, occupying the anterior half or more of the otolith. The postostial lobe is well developed and the ostium has a well-defined 


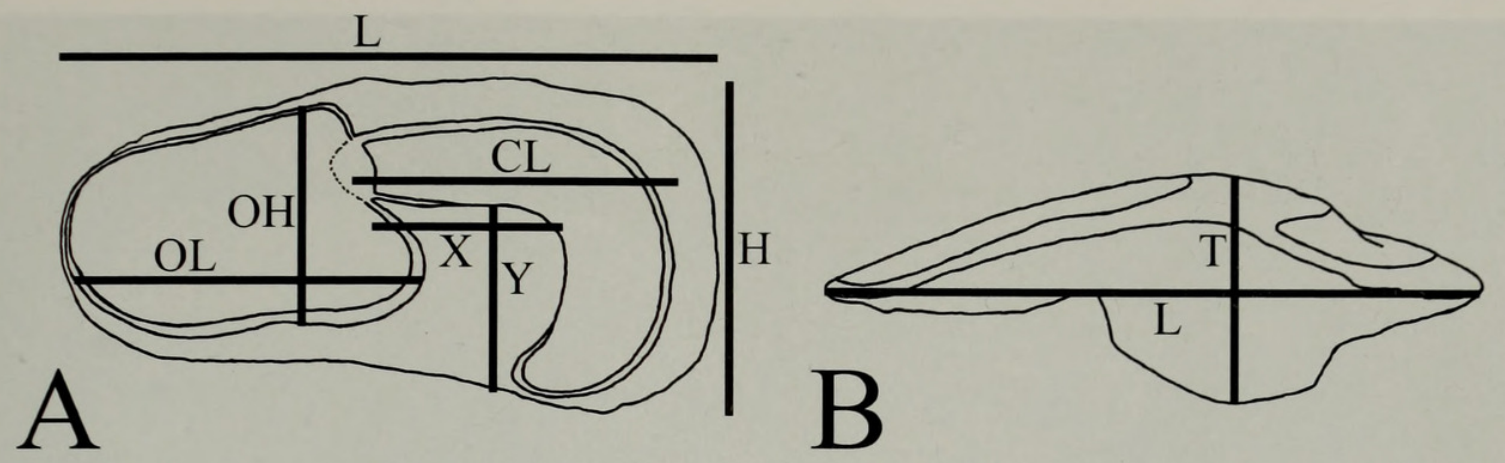

Fig. 3. Generalized sciaenid right saccular otolith with measurements used for proportional ratios. A. inner face; B. ventral view. Abbreviations: CL, cauda length; H, otolith height; L, otolith length; OH, ostium height; OL, ostium length; T, otolith thickness; X:Y, caudal curvature index (cci). Modified after Schwarzhans (1993).

midventral notch, with the dorsal margin generally straight. The narrow cauda arches dorsally from a precaudal depression, then is strongly curved, or bent ventrally. The anterior cauda is shorter or equal in length to the posterior cauda. The outer face of the otolith is moderately to strongly concave and sometimes has a bead-like postcentral umbo.

Totoaba fitchi, sp. nov.

Figures 4-5; Table 1

Holotype.-LACM 151552, left saccular otolith (Fig. 4).

Paratype.-LACM 151553, incomplete posterior right saccular otolith.

Referred specimens.-LACM 151554-151556, left saccular otoliths (Fig. 5); LACM 151557, incomplete posterior left saccular otolith (Fig. 5); LACM 151558, incomplete posterior right saccular otolith (Fig. 5).

Type locality.-LACM locality 6602, Barker's Ranch, Kern County, California; NW $1 / 4$ of Sec. 33, T. 28 S., R. 5 W., Rio Bravo Quadrangle, 7.5-minute Series, U.S.G.S., 1954.

Horizon.- - upper Olcese Sand, late early Miocene, upper Relizian Benthic Foraminiferal Stage.

Etymology. - The holotype is named in honor of the late John E. Fitch, formally of the California Department of Fish and Game, who recovered the otoliths of $T$. fitchi and for his significant contributions to the study of fossil and Recent otoliths.

Diagnosis. - The saccular otolith of T. fitchi is distinguished from the extant $T$. macdonaldi by the following combination of characters: a thicker, less elongated, subrectangular shape; the outer face is without a definable umbo; the inner face is only slightly convex; the ostium is larger; and the anterior cauda is much shorter than the length of the posterior cauda (see caudal curvature index (cci) in Table 1).

Discussion. - The saccular otolith of $T$. fitchi shows a number of characters diagnostic of Sciaenidae including: a strongly homosulcoid sulcus, with both the rostrum and antirostrum absent; a broad, flat, shallow ostium with a distinct postostial lobe; and a narrow horizontal anterior cauda with a curved posterior cauda. Within the Sciaenidae, this species also shows several characters diagnostic of the genus Totoaba including: a large subrectangular saccular otolith with a broadly rounded anterior end and blunted posterior end; enlarged shallow ostium with a 


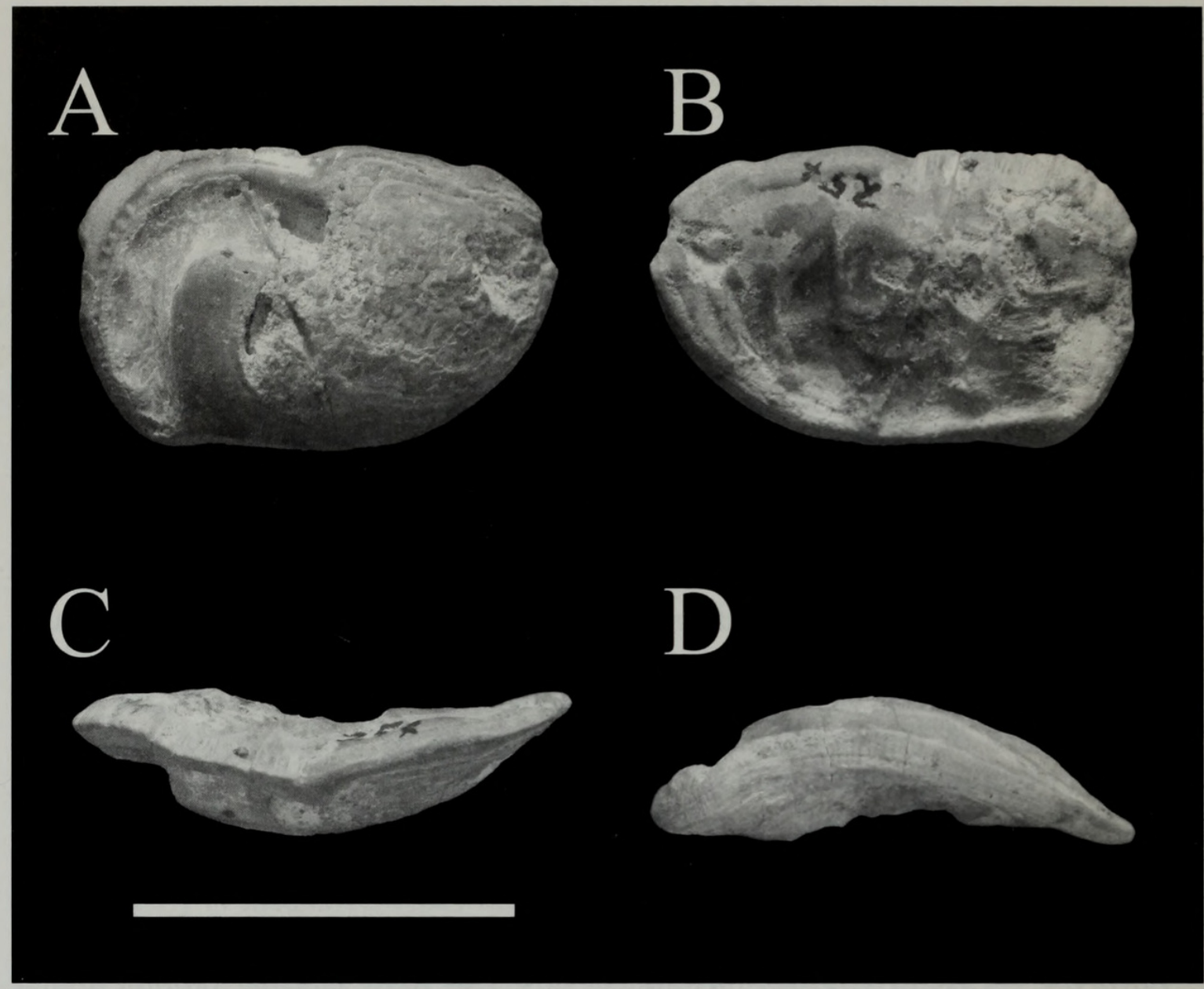

Fig. 4. Totoaba fitchi, sp. nov. (holotype; LACM 151552), left saccular otolith, late early Miocene, upper Olcese Sand, Kern County, California. A. inner face; B. outer face; C. dorsal view; D. ventral view. Scale bar equals $2 \mathrm{~cm}$.

well-developed postostial lobe and a midventral notch; a short anterior cauda; and an equal or longer posterior cauda.

Description. - A slightly elongate left adult saccular otolith with a subrectangular outline, and all margins rounded. The total length is $25.5 \mathrm{~mm}$, and the greatest height is $16.2 \mathrm{~mm}$. Measurements and proportional ratios for the saccular otolith of $T$. fitchi are summarized in Table 1 . The dorsal margin is nearly straight with a slight mediodorsal notch. The anterodorsal margin has a faint, low projection. The anterior margin is broadly rounded, and the ventral margin is nearly horizontal. The posterior margin is slightly blunted with a small dorsal flange present on the posterodorsal margin. The inner face is moderately convex with a pseudo-ostial sulcus. The ostium is large and spade-shaped, widening posteriorly, and occupying the anterior half of the otolith with a well-developed midventral notch. The postostial lobe is strongly developed, and the ostium is completely filled with a smooth, flat ostial colliculum. The cauda is moderately shallow and wide extending close to the posterior and posteroventral margins. The caudal joint is slightly constricted with the anterior cauda arching dorsally and then curving ventrally into a longer posterior cauda. The cauda tapers to a rounded point. The dorsal area is shallow, and the crista superior is well developed on the dorsal 


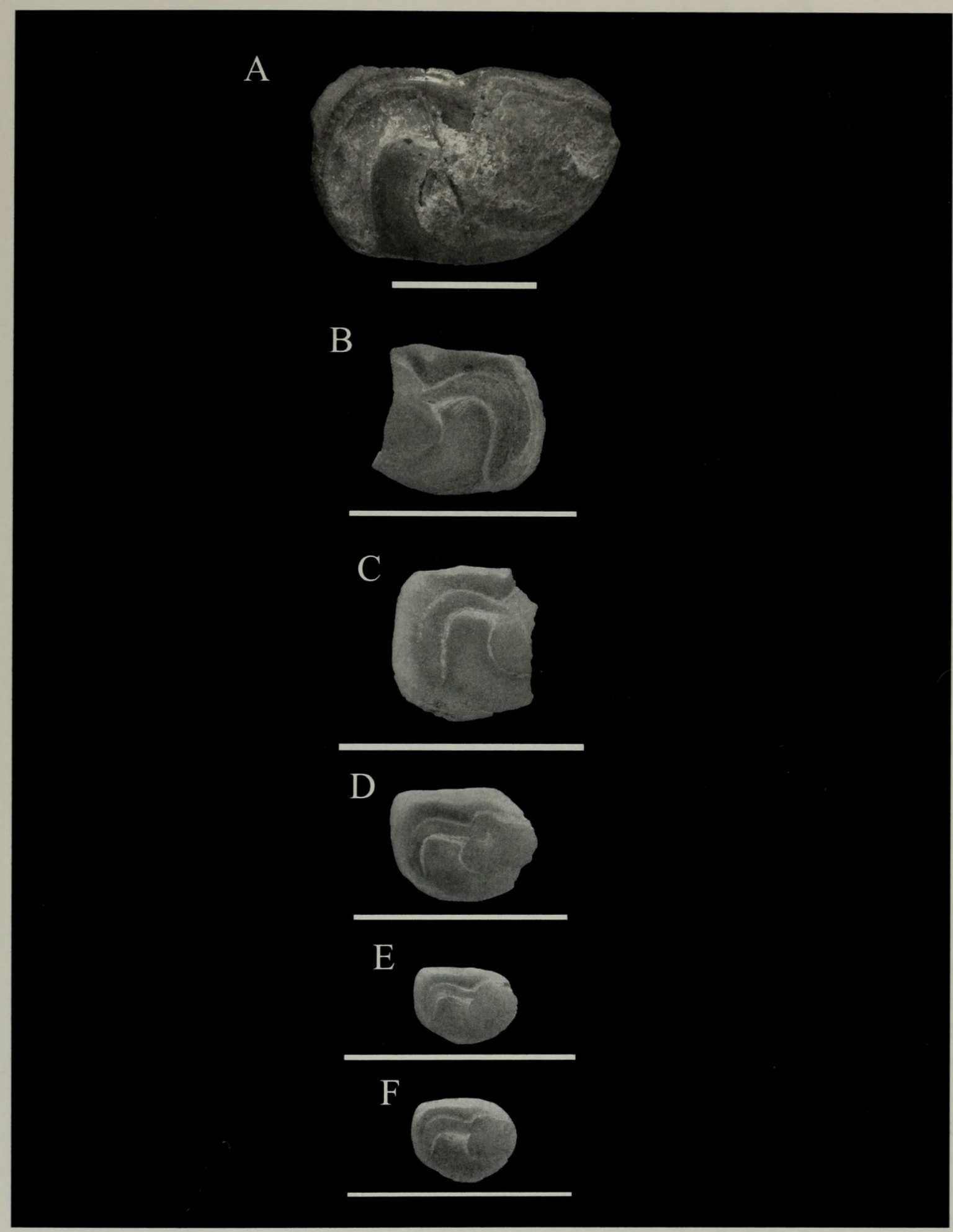

Fig. 5. Growth series of Totoaba fitchi, sp. nov. A. holotype, left saccular otolith, LACM 151552; B. incomplete posterior right saccular otolith, LACM 151558; C. incomplete posterior left saccular otolith, LACM 151557; D. left saccular otolith, LACM 151556; E. left saccular otolith, LACM 151555; F. left saccular otolith, LACM 151554. Scale bars equals $1 \mathrm{~cm}$. 


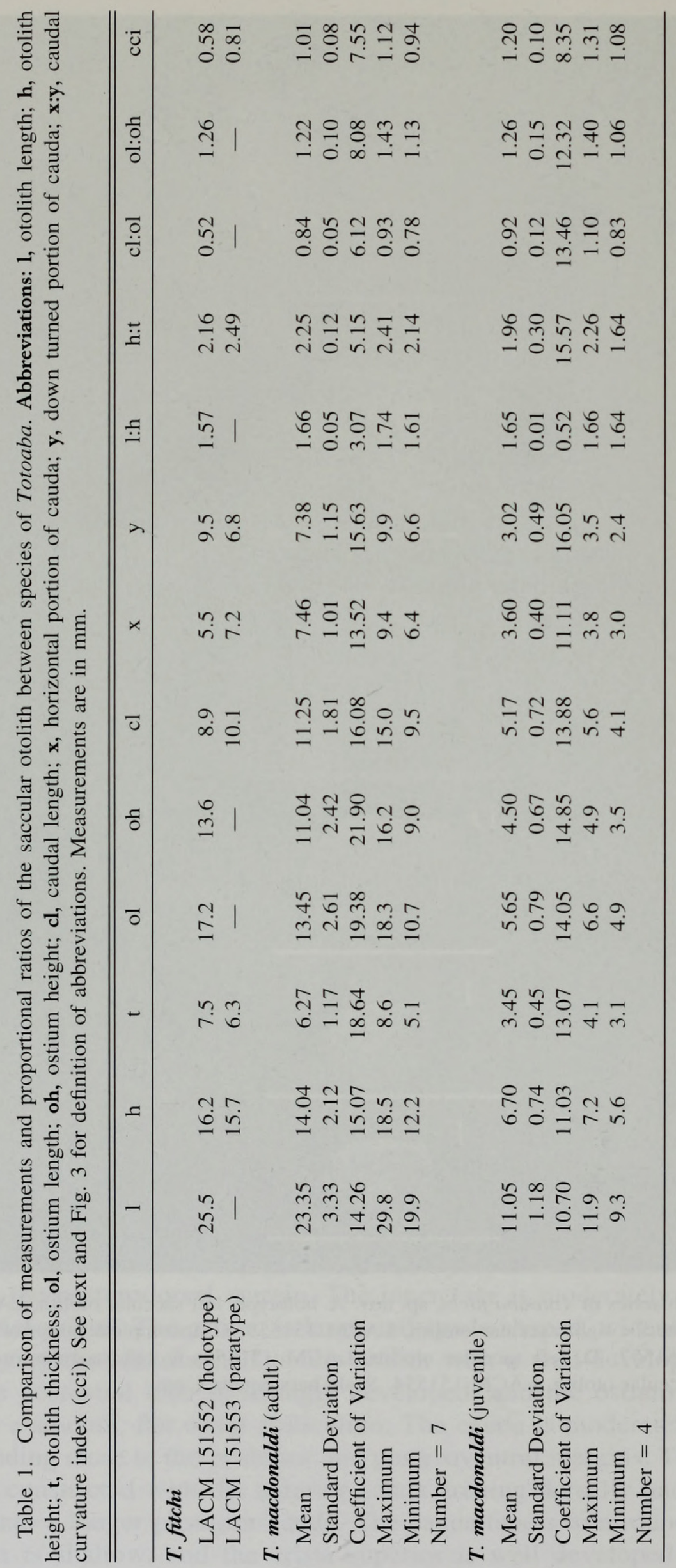


edge of the cauda margin. The outer face of the otolith is irregularly concave and thickens in the postcentral area but without a well-defined umbo.

\section{Discussion and Conclusions}

An important aspect in the study of fossil otoliths is the change that occurs in otolith morphology in relation to growth. The growth of saccular otoliths is proportional to the growth of the fish regardless of how the growth rate varies with time (Smale et al. 1995; Harvey et al. 2000). Otoliths at earlier juvenile stages generally exhibit a more pleisomorphic condition, while apomorphic characters evolve only in later developmental stages (Nolf 1985; Schwarzhans 1999). Sciaenid otoliths, in particular, display considerable ontogenetic change, and it is only in the late juvenile-early adult stage that all diagnostic features of the otolith become fully developed (Schwarzhans 1993).

Careful attention must be given to the morphological variations in otoliths caused by ontogeny; if unrecognized, these variations can lead to a number of taxonomic inaccuracies (Nolf 1985). The Sciaenidae possess particularly large saccular otoliths, sometimes exceeding $30 \mathrm{~mm}$ in length, and generally those less than $5-10 \mathrm{~mm}$ in length have not sufficiently developed the necessary diagnostic characters for accurate taxonomic assessment (Schwarzhans 1993). However, some groups of smaller sciaenids (e.g. Isopisthus Gill 1862, Leiostomus Lacepède 1802, Seriphus Ayres 1860, Menticirrhus Gill 1861, etc.) prove an exception to this rule, and all otoliths should be evaluated regardless of size. Only adult otoliths with fully developed characters should be used for type designation.

A series of six saccular otolilths of $T$. fitchi measuring $4.6 \mathrm{~mm}-25.5 \mathrm{~mm}$ in length (Fig. 5) allows us to propose an extended growth series for this species that reveals interesting allometric changes. These changes affect the major diagnostic characters of the otolith shape as well as sulcus morphology, which directly impact the reliability and level of identification possible. Without this reconstruction, several of the following otoliths would have remained unrecognized to genus or species. In the smallest otolith of $T$. fitchi (Fig. 5f), the characters are strongly pleisomorphic and possess only basic sciaenid features. The otolith is more ovate with a deep ventral margin. The dorsal margin is convex, and the posterodorsal margin is slightly angular with no posterodorsal projection. The ostium is small with no middorsal or midventral notch, and the postostial lobe is absent. The cauda is narrow with the anterior cauda slightly longer than the posterior cauda. As the otolith ontogenetically increases in size (Figs. 5d, e) it becomes more angular, while the dorsal margin is nearly horizontal. The ventral margin begins to shallow. The posterodorsal edge becomes angular, and the posterior margin is less curved with a dorsal and midventral notch on the ostium. The lengths of the anterior and posterior cauda are approximately equal. Otoliths at this stage have generic characters but are too generalized for species assignment. Even more mature, larger, otoliths (Figs. 5b, c) are subrectangular while the dorsal margin remains nearly flat and the posterior margin becomes more blunted. The posterodorsal margin is without a flange or projection, and the ostium has expanded to fill the anterior portion of the otolith. Otoliths of this size could only tentatively be assigned to species. In the fully adult stage (Fig. 5a; holotype), the otolith is subrectangular and slightly elongated with the posterior margin curved. The ostium has expanded to fill the anterior half or more of the otolith, and the dorsal 
margin of the ostium has become straight. The midventral notch has fully developed, with the postostial lobe present and the length of the anterior cauda is shorter than the posterior cauda. The width of the cauda has expanded, and a dorsal depression has developed. With the combination of these features, identification to species is possible.

The importance of constructing a growth series cannot be over emphasized. It provides a valuable tool in observing the development of diagnostic characters in the otolith. Caution must be exercised in selecting otoliths representing juvenile individuals in the sequence. Smaller otoliths are particularly sensitive to digestive erosion in the sulcus area and especially in the cauda. Nearly all isolated fossil otoliths have passed through the digestive system of predators prior to deposition (Nolf 1995) and are thus eroded to some degree.

Villamar (1980) hypothesized that the genus Totoaba is older than the formation of the Gulf of California, and T. macdonaldi evolved entirely in the Gulf. Current geological and geophysical studies of the complex origin and evolution of the Gulf of California indicate the opening of a Proto-gulf approximately 103.5 Ma (Karig and Jensky 1972; Helenes-Escamilla and Carreno 1999; Umhoefer et al. 2002), and its present configuration was established by the end of the Pliocene (Ledesma-Vazquez 2002). The occurrence of $T$. fitchi in the late early Miocene upper Olcese Sand supports Villamar's (1980) hypothesis and suggests that Totoaba, which is restricted to the northern Gulf of California today, appears to have evolved entirely in the eastern north Pacific Realm during, or prior to, the late early Miocene. The fossil record of the Sciaenidae is well documented in the Eocene to Oligocene of the Gulf Coast of North America (Koken 1888; Frizzell and Dante 1965; Breard and Stringer 1999; Nolf 2003; Nolf and Stringer 2003), and they do not appear along the Pacific Coast of North America until the early Miocene. Remarkably, sciaenids are totally absent from otolith rich Eocene deposits in southern California, and this absence has led us to hypothesize that the Sciaenidae initially invaded the eastern Pacific from the Gulf Coast region through the Panamanian Seaway sometime after the Eocene (Huddleston and Takeuchi 2006). Assuming that fossil Totoaba had similar ecological preferences as Recent Totoaba, the environment in the region of the Barker's Ranch area during the late early Miocene probably was a suitable habitat thoughout the year as suggested by the presence of both juvenile and adult Totoaba otoliths. Marine temperatures during the early and middle Miocene were warmer than off the Pacific coast of southern California today, and lower latitudinal gradients prevailed (Addicott 1970b; Olson 1987).

\section{Acknowledgments}

We are especially indebted to the late J. E. Fitch who found this locality and tirelessly collected the site over several years with various field parties including one of the authors (RWH). R. F. Feeney, J. A. Seigel, and C. Thacker (Department of Ichthyology, LACM) provided access to otoliths of extant and fossil sciaenids from the John E. Fitch Otolith Collection. P. A. Hastings, C. Klepadlo, and H. J. Walker, Jr. (Marine Vertebrate Collection, SIO) provided access to facilities and specimens. Thanks go to M. A. Roeder for graciously providing additional otoliths of T. macdonaldi from his personal collection for this study. Comments by C. A. Shaw and J. D. Stewart, and reviews by two anonymous reviewers greatly im- 
proved the clarity of this paper. Preliminary results of this project were presented at the 60th Annual Meeting of the Society of Vertebrate Paleontology.

\section{Literature Cited}

Addicott, W. O. 1956. Miocene stratigraphy northeast of Bakersfield, California. Ph.D. dissertation, Paleontology, University of California, Berkeley, California, 207 pp.

1970a. Miocene gastropods and biostratigraphy of the Kern River area, California. U. S. Geol. Surv. Prof. Pap., 642:1-174.

1970b. Tertiary paleoclimatic trends in the San Joaquin Basin, California. U. S. Geol. Surv. Prof. Pap., 644-D:1-19.

Ayres, W. O. 1860. [Description of fishes.] Proc. Calif. Acad. Sci. (Ser. 1), 77-81, 81-86.

Barnes, L. G. 1976. Outline of eastern North Pacific fossil cetacean assemblages. Syst. Zool., 25(4): 321-343.

, and E. D. Mitchell. 1984. Kentriodon obscurus (Kellogg, 1931), a fossil dolphin (Mammalia: Kentriodontidae) from the Miocene Sharktooth Hill Bonebed in California. Contrib. Sci., Nat. Hist. Mus. Los Angeles Co., 353:1-23.

Barrera-Guevara, J. C. 1990. The conservation of Totoaba macdonaldi (Gilbert), (Pisces: Sciaenidae), in the Gulf of California, Mexico. J. Fish Biol., 37 (Suppl. A):201-202.

Berdegue, A. J. 1955. La pesquería de la totoaba (Cynoscion macdonaldi Gilbert) en San Felipe, Baja, California. Rev. Soc. Mex. Hist. Nat., 16(1-4):45-78.

Breard, S. Q., and G. L. Stringer. 1995. Paleoenvironment of a diverse marine vertebrate fauna from the Yazoo Clay (Late Eocene) at Copenhagen, Caldwell Parish, Louisiana. Gulf Coast Assoc. Geol. Soc., 45:77-85.

1999. Integrated paleoecology and marine vertebrate fauna of the Stone City Formation (middle Eocene), Brazos River section, Texas. Trans. Gulf Coast Assoc. Geol. Soc., 49:132142.

Chao, L. N. 1995. Sciaenidae. Pp. 1427-1518 in Guia FAO para la identificacion de especies para los fines de la pesca. (W. Fischer, F. Krupp, W. Schneider, C. Sommer, K. E. Carpenter, and V. Niem, eds.), Pacifico Centro-oriental. Vol. III. Vertebrados-Parte 2. FAO, Rome, 1813 pp.

Cisneros-Mata, M. A., G. Montemayor-Lopez, and M. J. Roman-Rodriguez. 1995. Life history and conservation of Totoaba macdonaldi. Conserv. Biol., 9(4):806-814.

Clarke, M. E., and J. E. Fitch. 1979. Statoliths of Cenozoic teuthoid cephalopods from North America. Palaeontology, 22:479-511.

Cuvier, G. L. C. F. D. 1829. Le Règne Animal, distribué d'après son organisation, pour servir de base à l'histoire naturelle des animaux et d'introduction à l'anatomie comparée, Nouvelle édition. Paris, 2:122-406.

Flanagan, C. A., and J. R. Hendrickson. 1976. Observation on the commercial fishery and reproductive biology of the totoaba Cynocion macdonaldi, in the northern Gulf of California. Fish. Bull., 74(3):531-544.

Frizzell, D., and J. Dante. 1965. Otoliths of some early Cenozoic fishes of the Gulf Coast. J. Paleontol., 39:687-718.

Gaemers, P. A. M. 1984. Taxonomic position of the Cichlidae (Pisces, Perciformes) as demonstrated by the morphology of their otoliths. Neth. J. Zool., 34:566-595.

Gilbert, C. H. 1890. A preliminary report on the fishes collected by the steamer Albatross on the Pacific coast of North America during the year 1889, with descriptions of twelve new genera and ninety-two new species. Proc. U. S. Natl. Mus., 49-126.

Gill, T. N. 1861. Revision of the genera of North American Sciaeninae. Proc. Acad. Nat. Sci. Phila., 13:79-89.

1862. Note on the sciaenoids of California. Proc. Acad. Nat. Sci. Phila., 14:16-18.

Harvey, J. T., T. R. Loughlin, M. A. Perez, and D. S. Oxman. 2000. Relationship between fish size and otolith length for 63 species of fishes from the Eastern North Pacific Ocean. U. S. Dept. Commer., NOAA Tech. Rep. 150:1-36.

Helenes-Escamilla, J., and A. L. Carreno. 1999. Neogene sedimentary evolution of Baja California in relation to regional tectonics. J. So. Amer. Earth Sci., 12(6):589-605.

Herre, A. W. C. T. 1935. A new sciaenid from southeastern China. Lingnan Sci. J. Canton, 14(4): 603-604 
Huddleston, R. W., and G. T. Takeuchi. 2006. A new late Miocene species of sciaenid fish, based primarily on an in situ otolith from California. Bull. Southern California Acad. Sci., 105(1): 30-42.

Johnson, G. D., and C. Patterson. 1993. Percomorph phylogeny: a survey of the acanthomorphs and a new proposal. Pp. 554-626 in (G. D. Johnson and W. D. Anderson, Jr., eds.), Proceedings of the symposium on phylogeny of Percomorpha, June 15-17, held in Charleston, South Carolina at the $70^{\text {th }}$ annual meeting of the American Society of Ichthyologists and Herpetologists, Bull. Marine Sci., 52:1-629.

Karig, D. E., and W. Jensky. 1972. The Protogulf of California. Earth. Planet. Sci. Lett., 17:169-174.

Koken, E. 1888. Neue untersuchungen an Tertiären fischotolithen. Z. deut. Geol. Ges., 40:274-305.

Lacepède, B. G. E. 1802. Histoire naturelle des poissons. Hist. Nat. Poiss., 4:1-728.

Ledesma-Vazquez, J. 2002. A gap in the Pliocene invasion of seawater to the Gulf of California. Rev. Mex. Cienc. Geol., 19(3):145-151.

Lombarte, A., J. Rucabado, J. Matallanas, and D. Lloris. 1991. Taxonomia numerica de Nototheniidae en base a la forma de los otolitos. Sci. Mar., 55(2):413-418.

Mitchell, E. D. 1966. The Miocene pinniped Allodesmus. Univ. Calif. Publ. Geol. Sci., 61:1-105.

, and R. H. Tedford. 1973. The Enaliarctinae, a new group of extinct aquatic Carnivora and a consideration of the origin of the Otariidae. Bull. Am. Mus. Nat. Hist., 151(3):201-284.

Nelson, J. S. 2006. Fishes of the world, 4th ed. John Wiley and Sons, Inc., Hoboken, New Jersey, xix $+601 \mathrm{pp}$.

Nolf, D. 1985. Otolithi piscium. Pp. 1-145 in Handbook of Paleoichthyology Vol. 10. (H.-P. Schultze, ed.), Gustav Fischer Verlag, Stuttgart and New York.

. 1995. Studies on fossil otoliths - the state of the art. Pp. 513-544 in Recent developments in fish otolith research. (D. H. Secor, J. M. Dean, and S. E. Campana, eds.), Univ. South Carolina Press, 735 pp.

- 2003. Revision of the American otolith-based fish species described by Koken in 1888. Lou. Geol. Surv., 12:1-19.

, and E. Steurbaut. 1989. Evidence from otoliths for establishing relationships within gadiforms. Pp. 89-111 in Papers on the systematics of gadiform fishes. (D. M. Cohen, ed.), Nat. Hist. Mus. Los Angeles Co., Sci. Ser. 32, ix + 262 pp.

, and G. L. Stringer. 2003. Late Eocene (Priabonian) fish otoliths from the Yazoo Clay at Copenhagen, Louisiana. Lou. Geol. Surv., 13:1-23.

Olson, H. C. 1987. Biofacies zonation of Middle Miocene benthic foraminifera, southeastern San Joaquin Basin, California. AAPG Geol. Bull., 71(5):599.

1988. Oligocene-middle Miocene depositional systems north of Bakersfield, California: eastern equivalents of the Temblor Formation. Pp. 189-205 in Studies of the Geology of the San Joaquin Basin. (S. A. Graham, ed.), Pac. Section SEPM 60, 351 pp.

. 1990. Early and middle Miocene foraminiferal paleoenvironments, southeastern San Joaquin Basin, California. J. Foramin. Res., 20(4):289-311.

—, G. E. Miller, and J. A. Bartow. 1986. Stratigraphic, paleoenvironment and depositional setting of the Tertiary sediments, southeastern San Joaquin basin. 1986 Guidebook Pacific Section AAPG meeting, Bakersfield, California, 18-54.

Roman-Rodriguez, M. J., and M. G. Hammann. 1997. Age and growth of totoaba, Totoaba macdonaldi (Sciaenidae), in the upper Gulf of California. Fish. Bull., 95(3):620-628.

Sasaki, K. 1989. Phylogeny of the family Sciaenidae, with notes on its zoogeography (Teleostei, Perciformes). Mem. Fac. Fish. Hokkaido Univ., 36(1/2):1-137.

Savage, D. E., and L. G. Barnes. 1972. Miocene vertebrate geochronology of the west coast of North America. Pp. 124-145 in Proceedings of the Pacific Coast Miocene Biostratigraphic Symposium. (E. H. Stinemeyer, ed.), SEPM, 364 pp.

Schwarzhans, W. 1993. A comparative morphological treatise of recent and fossil otoliths of the family Sciaenidae (Perciformes), 1. In Piscium Catalogus, Otolithi Piscium. (F. Pfeil, ed.), Verlag Dr. Friedrich Pfeil, Munchen, 245 pp.

- 1999. A comparative morphological treatise of recent and fossil otoliths of the order Pleuronectiformes, 2. In Piscium Catalogus, Part Otolithi Piscium. (F. Pfeil, ed.), Verlag Dr. Friedrich Pfeil, Munchen, $391 \mathrm{pp}$.

Smale, M. J., G. Watson, and T. Hecht. 1995. Otolith atlas of Southern African marine fishes. Ichthyol. Monogr., J. L. B. Smith Inst. Ichthyol., 1:1-253. 
Stringer, G. L. 1998. Otolith-based fishes from the Bowden shell bed (Pliocene) of Jamaica: systematics and palaeoecology. Contr. Tert. Quatern. Geol., 35(1-4):147-160.

Takeuchi, G. T., and R. W. Huddleston. 2006. A Miocene chimaeroid fin spine from Kern County, California. Bull. Southern California Acad. Sci., 106(2):85-90.

Tedford, R. H., M. F. Skinner, R. W. Fields, J. M. Rensberger, D. P. Whistler, T. Galusha, B. E. Taylor, J. R. MacDonald, and S. D. Webb. 1987. Faunal succession and biochronology of the Arikareean through Hemphillian interval (late Oligocene through earliest Pliocene Epochs) in North America. Pp 153-210 in Cenozoic Mammal of North America. (M. O. Woodburne, ed.), University of California Press, Berkeley, Los Angeles, and London, xv + 336 pp.

Tedford, R. H., L. B. Albright, III, A. D. Barnosky, I. Ferrusquía-Villafranca, R. M. Hunt, Jr., J. E. Storer, C. C. Swisher, III, M. R. Voorhies, S. D. Webb, and D. P. Whistler. 2004. Mammalian biochronology of the Arikareean through Hemphillian interval (Late Oligocene through Early Pliocene Epochs). Pp. 169-231 in Late Cretaceous and Cenozoic Mammals of North America. (M. O. Woodburne, ed.), Columbia University Press, New York, xix +391 pp.

Umhoefer, P. J., L. Mayer, and R. J. Dorsey. 2002. Evolution of the margin of the Gulf of California near Loreto, Baja California Peninsula, Mexico. Geol. Soc. Am. Bull., 114(7):849-868.

Villamar, A. 1980. Totoaba, un nuevo género de la familia Sciaenidae del Golfo de California, México (Pisces: Teleostei). An. Esc. Nac. Cienc. Boil. Méx., 23:129-133.

Accepted for publication 29 June 2006. 


\section{$2 \mathrm{BHL}$ Biodiversity Heritage Library}

2007. "First fossil record of Totoaba Villamar 1980 (Teleostei: Sciaenidae) based upon early Miocene otoliths from California with comments on the ontogeny of the saccular otolith." Bulletin 106, 1-15. https://doi.org/10.3160/0038-3872(2007)106[1:FFROTV]2.0.CO;2.

View This Item Online: https://www.biodiversitylibrary.org/item/123214

DOI: https://doi.org/10.3160/0038-3872(2007)106[1:FFROTV]2.0.CO;2

Permalink: https://www.biodiversitylibrary.org/partpdf/50704

\section{Holding Institution}

California Academy of Sciences

\section{Sponsored by}

California Academy of Sciences Library

\section{Copyright \& Reuse}

Copyright Status: In copyright. Digitized with the permission of the rights holder.

This document was created from content at the Biodiversity Heritage Library, the world's largest open access digital library for biodiversity literature and archives. Visit BHL at https://www.biodiversitylibrary.org. 